\section{ECONOMICS}

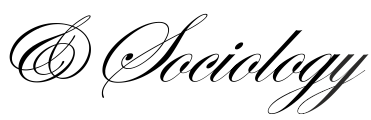

Chugaievska, S., Filipowicz, K., Tokarski, T., \& Wisła, R. (2020). Labour productivity simulations in Ukrainian regions: Analysis based on a gravitational growth model. Economics and Sociology, 13(4), 43-60. doi:10.14254/2071789X.2020/13-4/3

\title{
LABOUR PRODUCTIVITY SIMULATIONS IN UKRAINIAN REGIONS: ANALYSIS BASED ON A GRAVITATIONAL GROWTH MODEL
}

\section{Svitlana Chugaievska \\ Zhytomyr Ivan Franko State University, Zhytomyr, Ukraine \\ E-mail:scbugaevskaya@ukr.net \\ ORCID 0000-0002-9751-9647}

\section{Katarzyna Filipowicz}

Jagiellonian University in Krakow, Krakow, Poland

E-mail:k..filipowicz@uj.edu.pl

ORCID 0000-0003-2131-0414

\section{Tomasz Tokarski}

Jagiellonian University in Krakow, Krakow, Poland

E-mail:t.tokarski@uj.edu.pl

ORCID 0000-0002-9551-0892

\section{Rafał Wisła}

Jagiellonian University in Krakow, Krakow, Poland

E-mail:rafal.wisla@uj.edu.pl

ORCID 0000-0002-7895-6243

Received: February, 2020

1st Revision: September, 2020

Accepted: December, 2020

DOI: $10.14254 / 2071-$

789X.2020/13-4/3
ABSTRACT. The purpose of the article is to build a gravitational growth model of Ukrainian economy. The correlation of the labour productivity macroeconomic indicator and its empirical verification is considered. The article looks at recent research dealing with data analysis of region groups as of 2004-2017. To determine the conditions for economic development of the regions, the magnitude and the possible influence of the main macroeconomic factors were assessed. The methodology of gravity modelling makes it possible to study the significance of each individual factor on the basis of statistical information and to predict these factors within the context of possible scenarios. Methods of statistical analysis and econometric modelling were used to build a gravity model and to assess its statistical significance and forecasting ability for economy. The methodological principles of the gravity theory in the context of the set tasks involve studying both regional GDP indicators and the geographical location and remoteness from the capital. The paper presents the influence of two macroeconomic aggregates on the dynamics of economic development - labour productivity and physical capital per worker, with account of their relationship to gravitational effects. The economic analysis uses regional statistical data available on the website of the State Statistical Service of Ukraine. As a result, three main conclusions were formulated. First, 2001-2008 was the most favourable period for the development of Ukrainian economy (after the restoration of Ukraine's independence in 1991). Second, future strong positions of the Northern Ukraine were identified (Kyiv city, Kyiv region with account taken of the expected side effect). Third, a long-term one, to implement the regional development policy the volume of regional investment should be increased. In turn, investment attractiveness of the remote regions, with a relatively low expected economic polarization, will also increase.

Keywords: labour productivity, development diversification, gravitational growth model.
JEL Classification: E27, O11 


\section{Introduction}

In 1989 Ukraine was one of the republics within the Union of Soviet Socialist Republics, whose economy was part of an inefficient Soviet one. At the beginning of the 1990s, Ukraine was on its way to transformation of its economic system towards market economy but it lacked skills, knowledge, and institutions of parliamentary democracy for that. The collapse of the Union of Soviet Socialist Republics led to serious ruptures in the Soviet supply chain and the established economic ties. Internal imbalances (hyperinflation, rapid rise in the unemployment rate, production volume decline) and external factors (imminent depreciation of the national currencies, rapid imbalance in payments deficit and rising costs of foreign debt) were the macrocharacteristic of the first years of systemic changes in Ukraine.

During the 1990s Ukrainian GDP per capita (as in many other post-Soviet economies) remained barely steady. As a result, Ukraine's GDP per capita (at constant prices as of 2017) fell from $\$ 15,751$ (1990) to $\$ 6,700$ (1998). For comparison, during the same period Poland's GDP per capita grew from $\$ 11,317$ to $\$ 14,673$ (The World Bank, 2020).

Between 1999 and 2008, Ukraine's real GDP per capita increased by 95.5\%. Such positive results can be explained by the economic reforms related to the exchangeability of Ukrainian currency (hryvnia), stabilisation of inflation, increasing competitiveness of domestic production and creation of favourable conditions for the development of innovation and entrepreneurship (Emsina, 2014; Gricenko et al., 2015; Pustovoit, 2016).

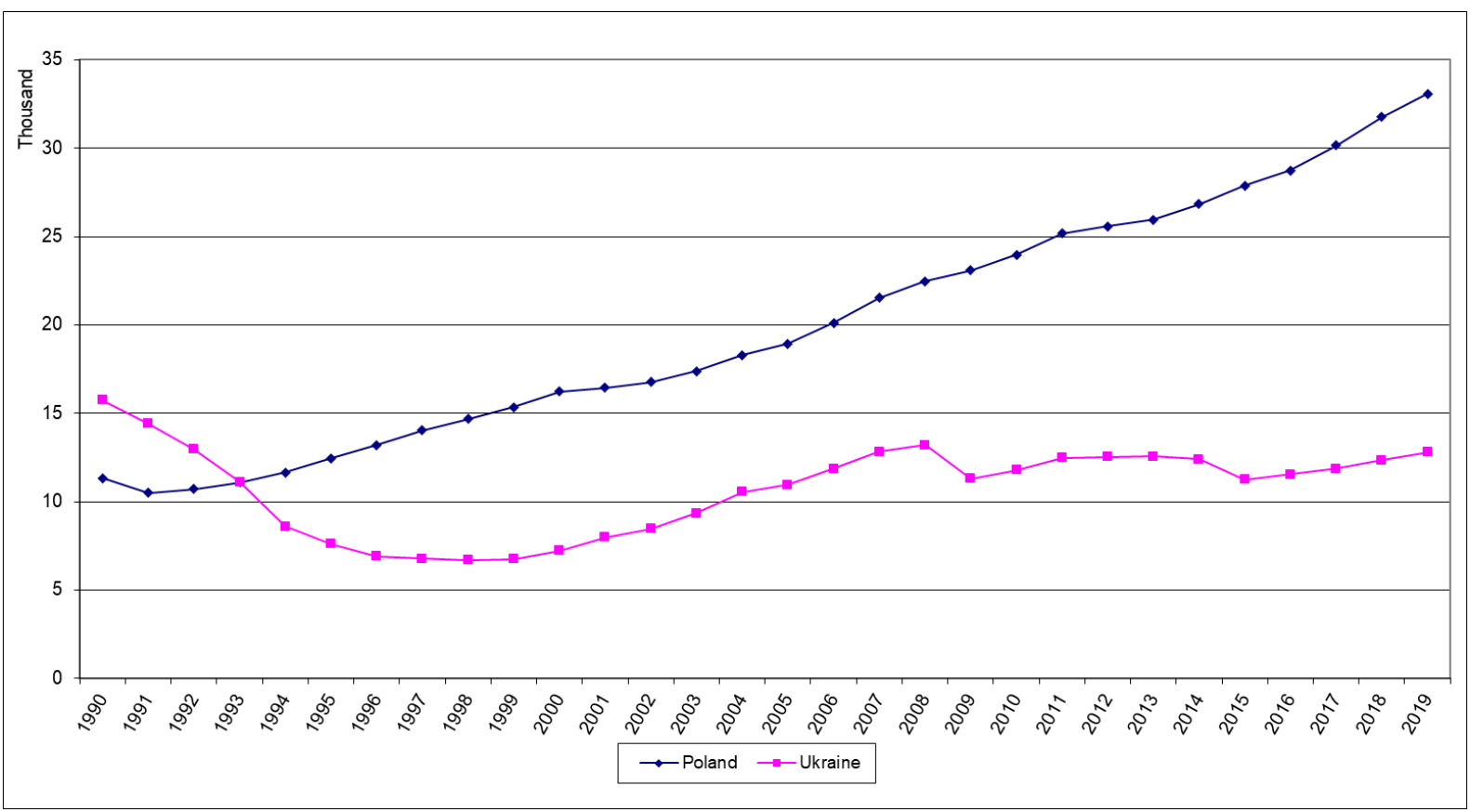

Figure 1. GDP per capita in Ukraine and in Poland, (USD at constant prices of 2017)

Source: The World Bank Group Indicators, GDP per capita:

https://data.worldbank.org/indicator/NY.GDP.PCAP.PP.KD?locations $=U A-P L \& v i e w=$ chart

The global financial crisis combined with the gas conflict with Russia led to a one-year recession in Ukraine in 2009. Ukrainian economy then grew rapidly again. This trend was changed by social and political instability after the Euro-Maidan 2013-2014 (the annexation of Crimea by Russia and the fight against pro-Russian separatists in the eastern part of Ukraine, in particular on the Donbas ${ }^{1}$ ). The crisis resulting from these events affected the financial sector

\footnotetext{
${ }^{1}$ Donbas is the Donetsk and Luhansk regions. The name Donbas comes from the Donetsk Coal Basin.
} 
(a 2/3 fall in deposits), led to high inflation, depreciation of the currency, it was also affecting the real economy (e.g., a fall in investment by about 50\%, growth in unemployment, etc.). The effects of political and social instability after the Euro-Maidan have also translated into wages. In 2017 , the average wage in the country amounted to only 192.2 USD, which was about $61.7 \%$ of the 2012 value (this is our own calculations based on the official statistical data of Ukraine). Such low wages caused a significant outflow of labour from the country. In 2018 the average wage level in Ukraine was 253 USD which was the lowest among all European countries. It is 4.7 times smaller than in Poland, 3.7 times smaller than in Russia and 2.2 times smaller than in Belarus. The lowest among all the Eastern European countries are also the indicators of labour productivity in Ukraine. In particular, whereas in Poland this figure was 29.1 USD per 1 hour back in 2017, it was only 2.8 USD in Ukraine, which is 10.4 times less. However, it should be emphasized that the rapid GDP growth in Ukraine during 2000-2008 led to a rise in employment in 2008 , by $5.0 \%$ as compared to 2001 (i.e., by about one million people) and a reduction in the unemployment rate, from $10.9 \%$ to $6.4 \%$. During 2010-2013 (i.e., during the period of the Russian-Ukrainian gas conflict and the Euro-Maidan), Ukrainian GDP grew again (the cumulative growth was at the time $6 \%$ ), which led to a $1 \%$ rise in employment as compared to an unemployment reduction by $1.5 \%$. After 2014, despite the GDP growth during 2015-2018, the employment rate has stabilized at around 16.3-16.4 mln people, and the unemployment rate - at around 9.3-9.5\%.

As the abovementioned implies, the article describes the influence of two macroeconomic aggregates on the dynamics of development processes - labour productivity and physical capital per worker as well as their connections with gravitational effects. The authors analyse the spatial differentiation of such macroeconomic variables as capital per worker and labour productivity (GDP per worker) in Ukrainian regions during 2004-2017. This analysis has been conducted on the basis of the gravitational model of economic growth as proposed by (Mroczek, Tokarski, Trojak, 2014) on the basis of theoretical aspects of macroeconomic development (Solow 1956; Romer 2000; Barro, Sala-i-Martin 2004; Acemoglu 2009; Aghion, Howitt 2009; Tokarski 2009, 2011) and macroeconomic development vector in Ukraine as proposed by Semykina (2010), Kozhem'iakina (2014), Zhurska (2018). In addition, the paper describes the calibrated parameters of this model and presents 8 variants of numerical simulations of trajectories of work efficiency enhancement in regions (oblasts) until 2050. In their empirical analyses, the authors used the regional statistical data publicly available on the website of the State Statistical Service of Ukraine (Urkstat.org).

\section{Gravitational growth model}

In this part of the study, the assumptions and properties of the gravitational model of economic growth will be described.

The gravitational growth model is characterized by the following assumptions:

1) Analysed is a finite number $\mathrm{N}>2(N \in \mathrm{N})$ of countries (or regions) ${ }^{2}$, between which there are spatial interactions of economic development. These interactions are described by the (individual or combined) effects of gravity to be characterised later.

\footnotetext{
${ }^{2}$ Hereafter, countries (regions) will also be called economies.
} 
2) The production process in the $j$-th economy is described by the Cobb-Douglas production function of 1928 . Hence it follows that labour productivity $y_{j}{ }^{3}$ in that economy may be captured using the equation ${ }^{4}$ (Źółtowska 1997; Tokarski 2009; 2011):

$$
\forall j \quad y_{j}(t)=a\left(g_{j}(t)\right)^{\beta}\left(k_{j}(t)\right)^{\alpha},
$$

where: $a>0, \alpha, \beta \in(0 ; 1)$ and $\beta<\frac{1-\alpha}{2}$. The expression $y_{j}$ means labour productivity in country (region) $j, k_{j}$ - the capital-labour ratio in that country (region), whereas $g_{j}^{\beta}$ in the function of labour productivity (1) describes that part of the total factor productivity in the economy $\left(a g_{j}^{\beta}\right) j$ which arises from the action of the gravity effect (this effect is described in assumptions 3-4). On the other hand $a>0$ is the part of the total factor productivity resulting from the action of certain factors that are not included in the further considerations. The parameter $\alpha$ is flexibility in production (or labour productivity) in terms of tangible capital expenditures (or capital-labour ratio). Parameter $\beta$, on the other hand is the flexibility of total factor productivity with respect to the combined effect of gravity, described by $g_{j}$.

3 ) Individual gravity effects, connecting country (region) $j$ with country (region) $m$ are described by the relationship:

$$
\forall j, m \wedge m \neq j \quad g_{j m}(t)=\frac{k_{j}(t) k_{m}(t)}{d_{j m}^{2}},
$$

where $\forall j, m \wedge m \neq j d_{j m}>0$ means the distance between the capital of the economy $j$ and the capital of economy $m$. By analogy with Newton's law of universal gravitation we also accept that the potency of the individual effects of gravity coupling two countries (regions) is directly proportional to their economic potential (measured by $k_{j}$ and $k_{m}$ ) and inversely proportional to the square of the distance between them. The adoption of an alternative assumption that the individual effects of gravity are described by the relationship:

$$
\forall j, m \wedge m \neq j \quad g_{j m}(t)=\frac{k_{j}(t) k_{m}(t)}{d_{j m}^{\gamma}},
$$

where $\gamma>0$ (i.e. that in the denominator of the individual effects of gravity - as in the macroeconomic analyses conducted in the gravity model of trade $-d_{j m}^{\gamma}$ appears, and not $d_{j m}^{2}$ ) does not significantly affect the stability of the model of growth in the model, nor do the conclusions of equations (8-9), or the golden rules of capital accumulation in the economic growth model under consideration.

\footnotetext{
${ }^{3}$ Labour productivity is calculated as real output (GDP, thou. UAH, prices of 2015) per person employed. Traditionally, in the Cobb-Douglas production function $Y_{i}$ uses for output expression; for labour productivity we uses $y_{i}$.

${ }^{4}$ For all occurring further macroeconomic variables, it is assumed that they are differentiable functions of time $t \geq 0$. $x(t)$ means the value of the variable $x$ at time $t$, while $\dot{x}(t)=d x / d t$ the derivative of $x$ at time $t$, i.e. (economically speaking) the increase in the value of that variable at time $t$. By contrast, $\forall j$ means $\forall j=1,2, \ldots, N$ , where $N>2$ is the number of countries (regions) analysed. The expressions $\sum_{j} x_{j}$ and $\prod_{j} x_{j}$ should be read similarly.

${ }^{5}$ The assumption that $\beta<\frac{1-\alpha}{2}$ in equation (1) is very important to show the stability of the non-trivial stationary point system of differential equations (7). This assumption means economically such that production flexibility with respect to the gravity effect is less than half of product flexibility in terms of labour inputs.
} 
4) The combined gravity effects (impacting on the economy $j$ ) are the geometric mean of the individual effects of gravity. This means that the following relations are fulfilled:

$$
\forall j \quad g_{j}(t)=\sqrt[N-1]{\prod_{m \neq j} g_{j m}(t)}
$$

5) As in the Solow growth model, the growth equations for capital-labour ratio in each of the countries (regions) are described by the following differential equations (Solow 1956; Romer 2000; Barro, Sala-i-Martin 2004; Acemoglu 2009; Aghion, Howitt 2009; Tokarski 2009, 2011): $\forall j \dot{k}_{j}(t)=s_{j} y_{j}(t)-\mu_{j} k_{j}(t)$,

where $\forall j s_{j} \in(0 ; 1) \wedge \mu_{j}>0$. The expression $s_{j}$ denotes the rates of investment in the $j$-th country (region), and $\mu_{j}$ - the rate of capital loss per worker in that country (region). The rates $\mu_{j}$ (for consecutive $j$ ) are the sums of capital depreciation and the rates of growth in the number of workers. formulas:

From equations (2-3) we obtain the equations for the total gravity effects given by the

$$
\forall j \quad g_{j}(t)=\frac{k_{j}(t)\left(\prod_{m \approx j} k_{m}(t)\right)^{\frac{1}{N-1}}}{d_{j}^{2}},
$$

where: $\forall j \quad d_{j}=\sqrt[N-11]{\prod_{m \neq j} d_{j m}}>0$. The expressions $d_{j}$ denote the distance geometric value of the capital of the $j$-th economy from the capitals of the other economies. Therefore, the lower the value assumed by $d_{j}$, the more centrally located is the $j$-th economy, while high values of $d_{j}$ are identical with the (geographically) peripheral nature of the $j$-th economy.

Substituting relationships (5) to equation (1) we have:

$$
\forall j \quad y_{j}(t)=\theta_{j}\left(\prod_{m \neq j} k_{m}(t)\right)^{\frac{\beta}{N-1}}\left(k_{j}(t)\right)^{\alpha+\beta},
$$

where: $\forall j \theta_{j}=\frac{a}{d_{j}^{2 \beta}}>0$.

From relations (4) and (6) we come to the following set of differential equations:

$$
\forall j \dot{k}_{j}(t)=s_{j} \theta_{j}\left(\prod_{m \neq j} k_{m}(t)\right)^{\frac{\beta}{N-1}}\left(k_{j}(t)\right)^{\alpha+\beta}-\mu_{j} k_{j}(t) .
$$

Using the Grobman-Hartman theorem we can show that the system of differential equations (7) has exactly one nontrivial stationary point $k^{*}=\left(k_{1}^{*}, k_{2}^{*}, \ldots, k_{N}^{*}\right)$ in the phase space $P=[0 ;+\infty)^{N}$, which is characterised by asymptotic stability ${ }^{6}$. Therefore, the point $k^{*}$ will hereafter be treated as the long-term equilibrium point for the gravity model of economic growth.

$\left(k_{j}^{*}\right)$

We can also show that, at the non-trivial stationary point $k^{*}$, the capital-labour ratio and labour productivity $\left(y_{j}^{*}\right)$ in the $j$-th country (region) are described by the equations:

\footnotetext{
${ }^{6}$ The system of differential equations ( 7$)$ also has the trivial solution $(0,0, \ldots, 0)$, which is, however, skipped hereon as uninteresting from an economic as well as a mathematical point of view.
} 
and:

$$
\forall j \ln k_{j}^{*}=\frac{\frac{\beta}{(N-1)(1-\alpha-2 \beta)} \sum_{m} \ln \frac{s_{m} a}{\mu_{m} d_{m}^{2 \beta}}+\ln \frac{s_{j} a}{\mu_{j} d_{j}^{2 \beta}}}{1-\alpha-\frac{N-2}{N-1} \beta} .
$$

$$
\begin{aligned}
& \forall j \ln y_{j}^{*}=\ln \frac{a}{d_{j}^{2 \beta}}+\frac{\alpha+\frac{N-2}{N-1} \beta}{1-\alpha-\frac{N-2}{N-1} \beta} \ln \frac{s_{j} a}{\mu_{j} d_{j}^{2 \beta}}+ \\
& +\frac{\beta}{(N-1)(1-\alpha-2 \beta)\left(1-\alpha-\frac{N-2}{N-1} \beta\right)} \sum_{m} \ln \frac{s_{m} a}{\mu_{m} d_{m}^{2 \beta}} .
\end{aligned}
$$

From equations (8-9), the following four conclusions are drawn. Firstly, the long-term resource of capital-labour ratio and the flow of labour productivity in country (region) $j$, as is the case in the original Solow model, is the higher, the higher the rate of investment $s_{j}$, and the lower the rate of capital loss per worker $\mu_{j}$ in that country (region). Secondly, the more centrally located an economy is, that is, the lower the distance geometric value $d_{j m}$, the higher the level of both capital-labour ratio and labour productivity in conditions of long-term equilibrium of the gravity model of economic growth. Thirdly, the levels of macroeconomic variables considered here in $j$-th country (region) are higher, the higher the geometric value $\sqrt[N-1]{\prod_{m \neq j} s_{m}}$ from investment rates in the other countries (regions) and the lower the geometric value $\sqrt[N-1]{\prod_{m \neq j} \mu_{m}}$ of the rates of capital loss per worker in these countries (regions). Fourthly, the level of labour productivity and capital-labour ratio in the $j$-th economy in the conditions of longterm equilibrium are also affected by the extra gravitational part of total factor productivity $a$. Moreover, the higher $a$, the higher the values of $y_{j}^{*}$ and $k_{j}^{*}$.

As it is seen from the presented growth model there is a correlation between the economic development level / state of economy (measured by labour productivity) and the gravitational potential. Thus areas with a high gravitational potential usually have a higher economic development level / state of economy than areas with a lower gravitational potential. Gravitational influence can either trigger a maturity of economy or, in the case of a weak gravitational effect, it can lead to even greater peripherization. The weak gravitational potential does not mean that there are no economic outlook / economic prospects for a given area, as it can be balanced by relevant investment. Peripheral regions (with low gravitational potential) require additional investment. Consequently, due investment of these regions should be considered as a development basis for their economic advancement.

\section{Spatial diversification of capital per worker, gravitational effects and labour productivity}

Ukraine is divided administratively into 24 regions (oblasts), the Autonomous Republic of Crimea and 2 cities with special status: Kyiv and Sevastopol. Since 2014, the Autonomous Republic of Crimea and Sevastopol have been occupied by the Russian Federation. Consequently, the statistics for the Autonomous Republic of Crimea and Sevastopol refer to the years 2004-2013 or 2004-2014. 
The spatial diversification of capita-labour ratio in Ukrainian regions in $2004-2016^{7}$ is presented in Map 1. The capital city of Kyiv (667.6 thou. UAH) was characterised by far the highest value of this macroeconomic variability. This is due to the fact that the city has by far the largest demographic potential in Ukraine (in 2016 the population of Kyiv was over 2.9 million people, while the second largest city - Kharkiv - about 1.4 million) and, secondly, it is the country's administrative and service centre ${ }^{8}$. This variablity was followed by Kyiv oblast (253.3 thou. UAH), Donetsk oblast (234.6 thou. UAH), Dnipropetrovsk region (228.0 thou. UAH) and Zaporizhzhia region (193.3 thou. UAH). Both these are strictly industrial oblasts (Donetsk and Zaporizhzhia), the Kyiv oblast constituting the natural surroundings of the capital and the perimeter of Dnipropetrovsk, whose capital Dnipro ${ }^{9}$ is the centre of financial services in Ukraine.

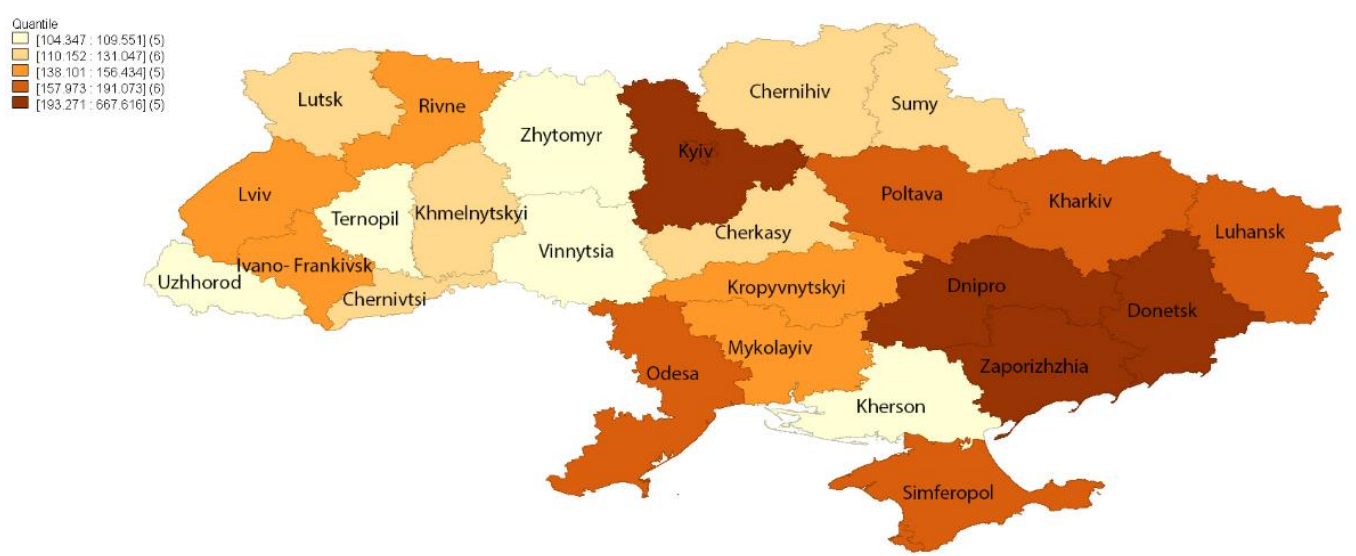

Map 1. Capita-labour ratio in Ukrainian regions in 2004-2017 (thou. UAH, prices of 2015) in the case of Autonomous Republic of Crimea and Sevastopol, 2004-2013

Source: own calculation based on http://www.ukrstat.gov.ua

The most of the regions with the highest or high capital per worker are located in LeftBank Ukraine (with the exception of the Odessa regions in Right-Bank Ukraine and Kyiv oblast and Kyiv city on both sides of the Dnieper $)^{10}$. On the other hand, the oblasts of Right-Bank Ukraine were generally characterised by a lower level of capital per worker than those located to the east of the Dnieper River.

Such spatial diversification of capital per worker in Ukraine's oblasts can be explained to a large extent by historical reasons. This is due to the fact that the areas located in the LeftBank Ukraine and on the Black Sea, before World War I and during the Soviet Union, were much more economically integrated with the territory of the present Russian Federation than the Right-Bank Ukraine. The Right-Bank territory of Ukraine (with the exception of Odesa and Mykolayiv regions) was located on the outskirts of the Russian Empire and Austro-Hungarian Empire before World War I. The changing zones of political influence in Right-Bank Ukraine weakened the economic areas, while Left-Bank Ukraine and the Black Sea regions were

\footnotetext{
${ }^{7}$ All the following macroeconomic values expressed in monetary units are converted into fixed prices in 2015. Since, according to UNECE (https://w3.unece.org/PXWeb/en), Ukraine's GDP per capita this year was 46,413 hryvnia, and according to the PPP 7949 USD, 100 UAH was equivalent to 17.1 USD.

${ }^{8}$ The fact that the country's capital is the most developed city is by no means the rule in all European countries. The best developed German cities are Hamburg and Munich, not the capital city of Berlin, while in Italy the capital region of Lazio is much less developed than Lombardy or Trentino-Alto Adige in northern Italy (cf. e.g. Pastuszka, Tokarski 2017).

${ }^{9}$ Until 2016 the city of Dnipro was called Dnipropetrovsk, Kropyvnytskyi - Kirovograd.

${ }^{10}$ Historically, Left-bank (Right-bank) Ukraine is the part of the country that lies to the left (right) of the largest Ukrainian river, the Dnieper River.
} 
relatively stable politically up to Euro-Maidan (cf. e.g. Hrycak 2000, Serczyk 2001 or Hud 2018).

Map 2 shows the spatial differentiation of national gravity effects in Ukraine. National gravity effects are understood as combined gravitational effects by described equation (3) in the theoretical model. The economic potential of the districts is measured by the capital per worker, while the distances $d_{i j}$ between the capitals of the regions were calculated using their geographical coordinates and Pythagoras theorem (in the case of Kyiv region, the geographical coordinates of the largest city of the district, Bila Tserkva, were used). These distances are expressed in geographical minutes (mingeo).

The spatial differentiation of national gravity effects illustrated in map 2 shows the following. First of all, as in the case of technical work equipment, by far the highest level of these effects was observed in Kyiv (1.622 million hryvnia ${ }^{2} / \mathrm{mingeo}^{2}$ ). Secondly, it was followed by the Kyiv $\left(0.688\right.$ million hryvnia $^{2} /$ mingeo $\left.^{2}\right)$, Dnipropetrovsk $(0.458$ million hryvnia ${ }^{2} /$ mingeo $\left.^{2}\right)$, Poltava $\left(0.390\right.$ million hryvnia $^{2} /$ mingeo $\left.^{2}\right)$ and Kirovohrad regions $(0.384$ million hryvnia ${ }^{2} /$ mingeo $\left.^{2}\right)$.

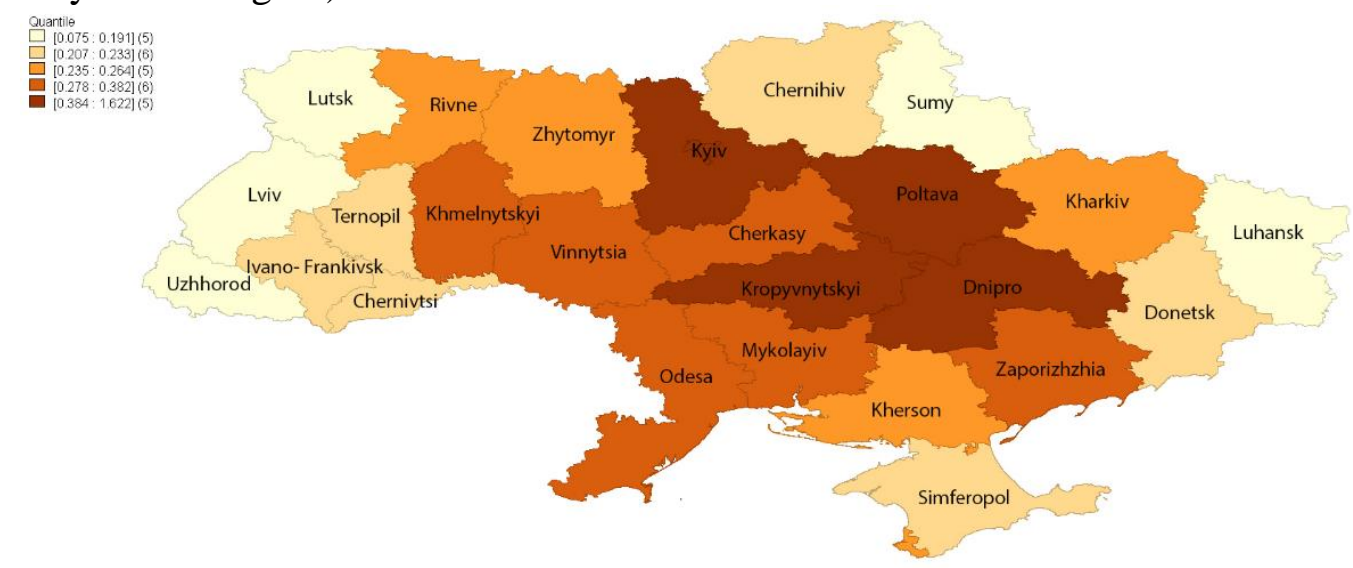

Map 2. Domestic gravity effects in Ukrainian regions in 2004-2017 (millions of hryvna $^{2} /$ mingeo $^{2}$, prices of 2015) in the case of Autonomous Republic of Crimea and Sevastopol in 2004-2013

Source: own calculation based on http://www.ukrstat.gov.ua.

These are therefore the districts on the Dnieper River or in Left-Bank Ukraine. Thirdly, the lowest values of these effects were recorded in Lviv $\left(0.191\right.$ million hryvnia $\left.^{2} / \mathrm{mingeo}^{2}\right)$, Volyn region $\left(0.187\right.$ million hryvnia ${ }^{2} /$ mingeo $\left.^{2}\right)$ with the centre in Lutsk, Sumy $(0.176$ million hryvnia ${ }^{2} /$ mingeo $\left.^{2}\right)$, Luhansk $\left(0.110\right.$ million hryvnia $^{2} /$ mingeo $\left.^{2}\right)$ and Zakarpattia $(0.075$ million hryvnia $^{2} /$ mingeo $^{2}$ ) oblasts with the centre in Uzhhorod. Lviv, Volyn and Zakarpattia regions are located close to the Polish border (Zakarpattia, also to the Slovak and Hungarian), while Luhansk and Sumy oblasts are located near the Russian border. These are therefore peripheral regions in relation to Ukraine's strongest economic centre - Kyiv (cf. also Chugaievska et. al. 2017, 2018).

Maps 3 and 4 illustrate the spatial differentiation of the so-called external gravitational effects connecting Ukrainian regions with Poland (map 3) and Russia (map 4) respectively. These effects were calculated analogously to the national gravity effects with the difference that the economic potential measured by physical capital per worker of the entire Polish and Russian economies was taken into account and the distances of the capitals of successive oblasts from Warsaw and Moscow were used.

Map 3 shows the following. Firstly, the highest foreign gravity effects from Poland were observed in the Lviv region (Western Ukraine) (1.567 million hryvnia ${ }^{2} /$ mingeo $^{2}$ ), Zakarpattia (1.069 million hryvnia ${ }^{2} /$ mingeo $\left.^{2}\right)$, Volyn $\left(0.862\right.$ million hryvnia $^{2} /$ mingeo $\left.^{2}\right)$, Ivano-Frankivsk 
regions $\left(0.856\right.$ million hryvnia $\left.^{2} / \mathrm{mingeo}^{2}\right)$ and Kyiv capital $\left(1.140\right.$ million hryvnia $\left.{ }^{2} / \mathrm{mingeo}^{2}\right)$. Secondly, due to their geographical location, the Right-Bank Ukraine's oblasts were characterised by a lower value of these effects than those in the Left-Bank Ukraine.

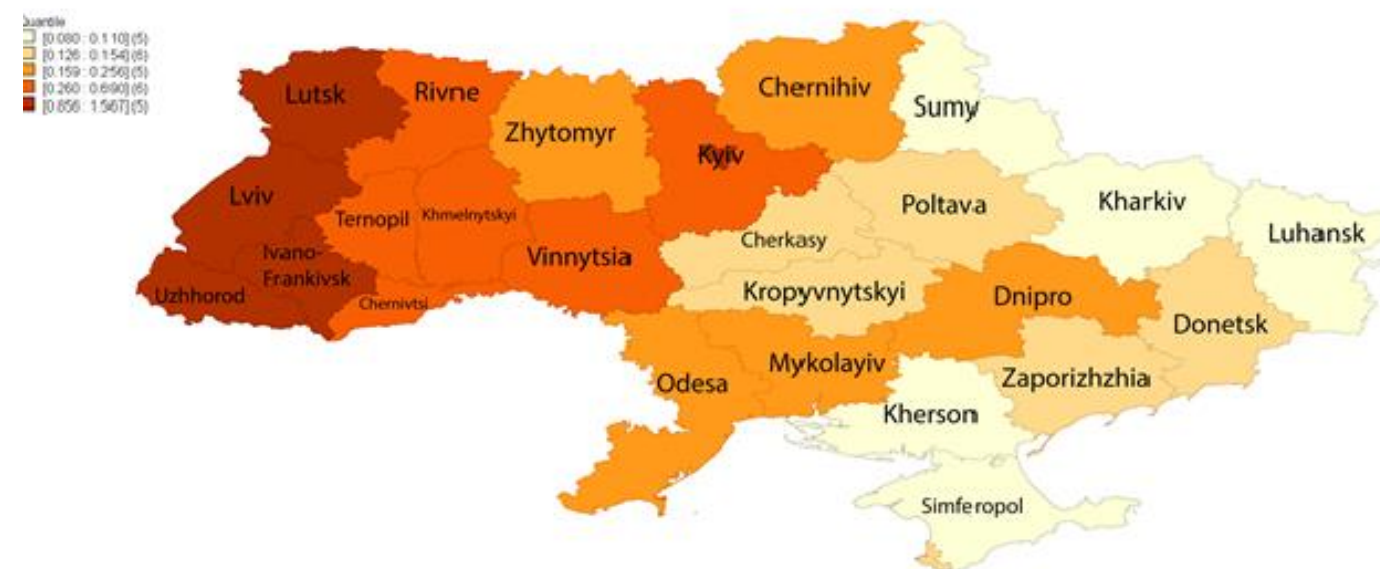

Map 3. Foreign gravity effects from Poland in Ukrainian regions in 2004-2017 (million of hryvnia $^{2} /$ mingeo $^{2}$, prices of 2015) in the case of Autonomous Republic of Crimea and Sevastopol in 2004-2013

Source: own calculation based on http://www.ukrstat.gov.ua/ .

On the other hand, the external gravitational effects from Russia illustrated on map 4 were strongest in the Dnieper Valley (Kiev 1.423 million hryvnia ${ }^{2} /$ mingeo $^{2}$, Poltava 0.658 million hryvnia ${ }^{2} / \mathrm{mingeo}^{2}$, and Dnipropetrovsk oblasts $0.624 \mathrm{million} \mathrm{hryvnia}^{2} / \mathrm{mingeo}^{2}$ ) and in the regions near Russia: Kharkiv (0.793 million hryvnia ${ }^{2} /$ mingeo $\left.^{2}\right)$, Donetsk $(0.656$ million hryvnia $^{2} /$ mingeo $\left.^{2}\right)$, Sumy (0.559 million hryvnia ${ }^{2} /$ mingeo $\left.^{2}\right)$ and Luhansk (0.532 million hryvnia $^{2} /$ mingeo $^{2}$ ).

Due to its geographical location, Left-Bank Ukraine was characterised by a much higher level of foreign gravitational effects made by Russia than Right-Bank Ukraine (the strength of external gravitational effects made by Russia in the border Ukrainian-Slovak-Hungarian Zakarpattia oblast was only about $4.2 \%$ of the strength of these effects in Kyiv, the capital city).

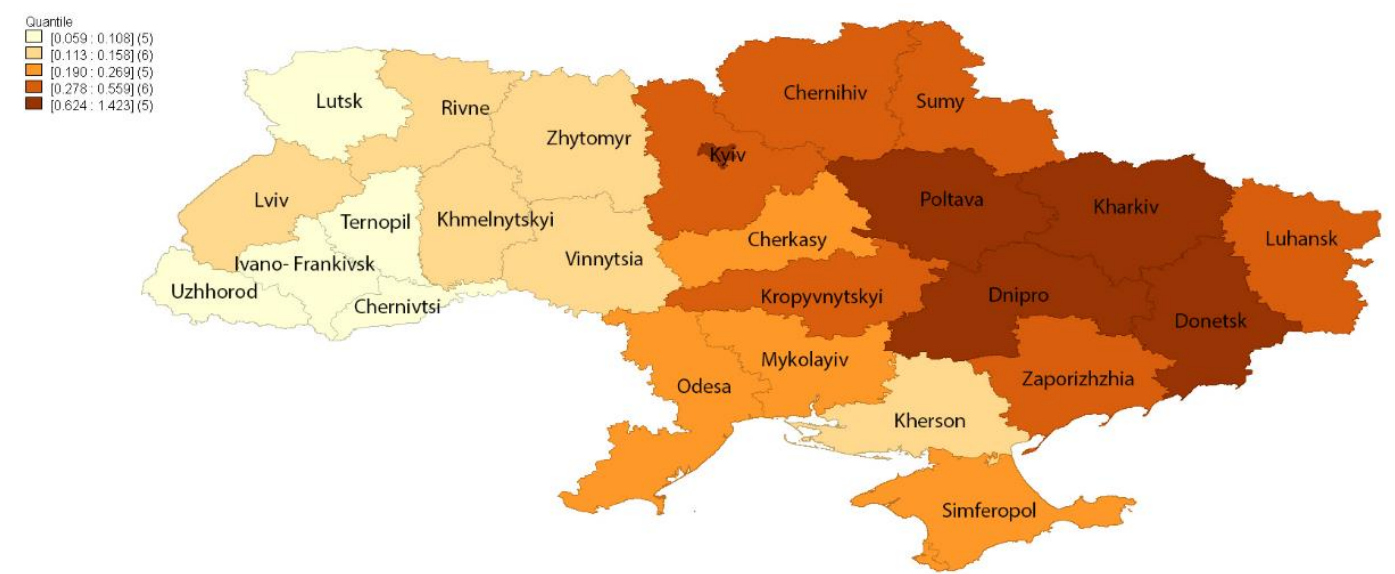

Map 4. Foreign gravity effects from Russia in Ukrainian regions in 2004-2017 (millions of hryvnia $^{2} /$ mingeo $^{2}$, prices of 2015) in the case of Autonomous Republic of Crimea and Sevastopol in 2004-2013

Source: own calculation based on http://www.ukrstat.gov.ua. 
Map 5 shows the spatial variation in labour productivity in Ukrainian oblasts. The following conclusions can be drawn from this map. First of all, the capital city of Kyiv (367.4 thou. UAH) had by far the highest level of this variable. Secondly, next were Dnipropetrovsk $(175,800 \mathrm{UAH})$, Poltava (166,700 UAH) and Kyiv (147,800 UAH) in the Dnieper Valley, and Donetsk (160,400 hryvnia) in Eastern Ukraine. Thirdly, a high level of this variable was also recorded in Eastern Ukraine lying in the industrial regions - Zaporizhzhia (135.9 thou. UAH), Kharkiv (124.5 thou. UAH) and Luhansk (105.1 thou. UAH), located in the South of Ukraine Odesa (121.7 thou. UAH), Mykolayiv (108.5 thou. UAH), Sevastopol (102.4 thou. UAH) and situated in the West of Ukraine - Ivano-Frankivsk (102.4 thou. UAH). Fourthly, the lowest labour productivity values were recorded in Ternopil (76.1 thou. UAH), Zakarpattia (71.4 thou. UAH) and Chernivtsi (65.1 thou. UAH) regions in Western Ukraine and Zhytomyr (82.6 thou. UAH) in Northern Ukraine and Kherson (78.9 thou. UAH) in Southern Ukraine. Sixthly, the areas of Left-Bank Ukraine and the Odesa and Mykolayiv coastal oblasts (formerly more economically integrated with Russia) in the South of the country were generally characterised by a higher level of the variable under consideration than the other Ukrainian regions.

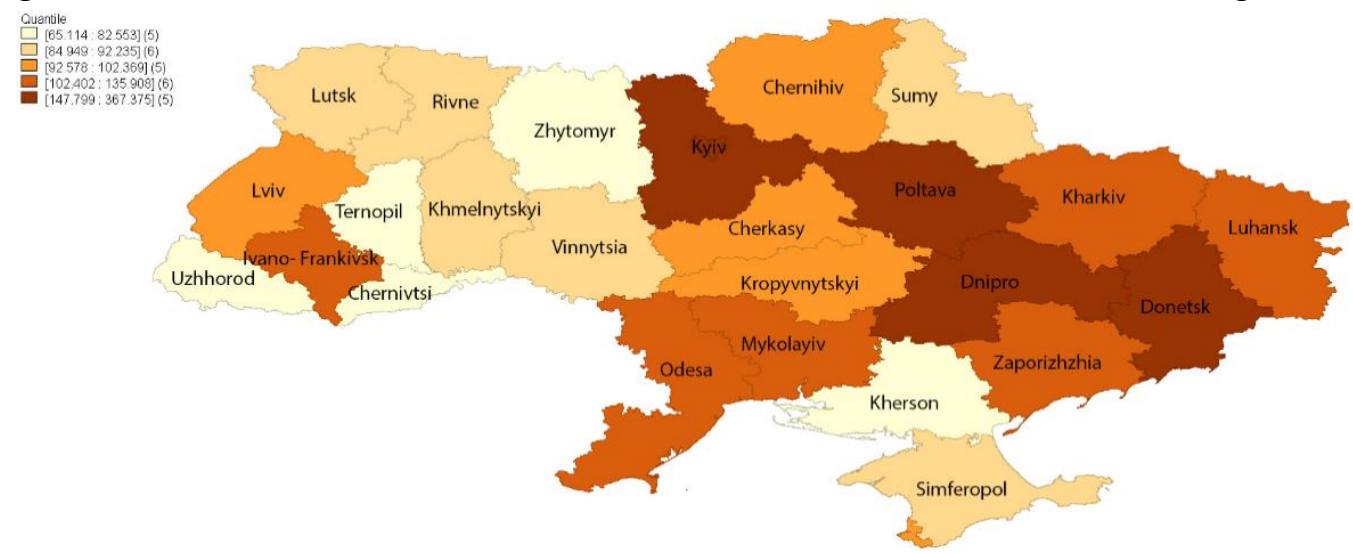

Map 5. Labour productivity in Ukrainian regions in 2004-2017 (thou. UAH, prices of 2015) in the case of Autonomous Republic of Crimea and Sevastopol in 2004-2013

Source: own calculation based on http://www.ukrstat.gov.ua.

For further research on labour productivity, investment rates and simulation of labour productivity growth ways, the Ukrainian regions were divided into 5 groups (macro-regions). These groups are the regions of Western Ukraine (Khmelnytskyi, Chernivtsi, Ivano-Frankivsk, Lviv, Rivne, Ternopil, Volyn and Zakarpattia oblasts), Northern Ukraine (Kyiv and its oblasts: Chernihiv, Kyiv, Sumy and Zhytomyr), Eastern Ukraine (Kharkiv, Donetsk, Luhansk and Zaporizhzhya), Southern Ukraine (Autonomous Republic of Crimea, Kherson, Mykolayiv, Odesa and Sevastopol oblasts) and Central Ukraine (Cherkasy, Dnipropetrovsk, Kropyvnytskyi, Poltava and Vinnytsia). In 201510.7 million people lived in Western Ukraine's regions (24.9\% of the population of Ukraine), with a GDP of 322.7 billion hryvnia (16.2\% of Ukraine's GDP). In the remaining groups of oblasts, these indices were respectively: 8.0 million inhabitants (18.8\%) and 672.7 billion hryvnia (33.8\%) in Northern Ukraine, 11.0 million inhabitants $(25.6 \%)$ and 352.8 billion hryvnia (17.7\%) in Eastern Ukraine, 4.6 million inhabitants (10.8\%) and 180.2 billion hryvnia (9.1\%) in Southern Ukraine without the Autonomous Republic of Crimea and Sevastopol, and 8.5 million people (19.9\%) and 460.2 billion hryvnia $(23.1 \%)$ in Central Ukraine ${ }^{11}$.

\footnotetext{
${ }^{11}$ In 2013 (before the annexation of the Crimean Peninsula by Russia) 23.5\% of the population of Ukraine lived in Western Ukraine, $17.7 \%$ in Northern Ukraine, $24.5 \%$ in Eastern Ukraine, $15.4 \%$ in Southern Ukraine and $18.0 \%$ in Central Ukraine. They produced there respectively: $14.4 \%$ of Ukrainian GDP (Western Ukraine), 30.1\%
} 
Eastern Ukraine oblasts are among the most urbanised in Ukraine (the urbanisation rate in these districts was $85.3 \%$ in 2015). In terms of this indicator, the regions of Northern Ukraine (76.5\%), Central Ukraine (67.5\%), Southern Ukraine (65.9\%) were the next in order, while the smallest percentage of population living in cities was observed in Western Ukraine oblasts 49.9\%. Of the 10 largest Ukrainian cities, 1 is located in Western Ukraine (Lviv), 1 - in Northern Ukraine (Kyiv), 4 - in Eastern Ukraine (Kharkiv, Donetsk, Zaporizhzhia and Mariupol) and 2 each in Southern Ukraine (Odesa and Mykolayiv) and Central Ukraine (Dnipro and Krzywy Rig, cf. Chugaievska, Tokarski 2018).

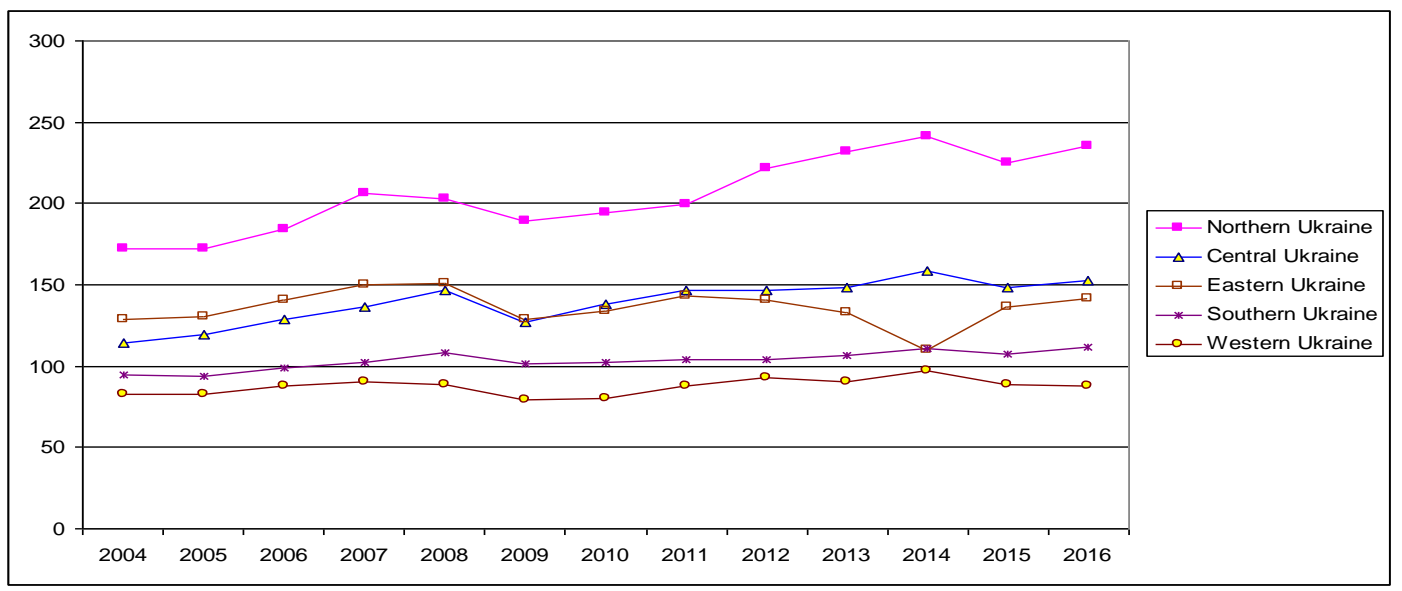

Figure 2. Labour productivity in the groups of Ukrainian oblasts in 2004-2016 (thou. UAH, prices of 2015)

Source: own calculation based on http://www.ukrstat.gov.ua.

Figure 2 shows the trajectories of labour productivity in the groups of Ukrainian oblasts in the years 2004-2016. Analysing these trajectories, the following conclusions can be drawn. Firstly, the ways of labour productivity growth in each of these groups of oblasts were similar to the ways of labour productivity growth and GDP in the whole Ukrainian economy. Thus, until 2007, the values of these variables increased, in 2008-2009 they decreased, to grow again until Euro-Maidan, and then decrease with a slight upturn in 2016. Secondly, by far the highest value of this variability in the analysed period was found in the Northern Ukraine, which was mainly due to the fact that Kyiv and Kyiv region are located there.

Thirdly, in 2004 the GDP per worker in North Ukraine was 33.9\% higher than the labour productivity in industrial Eastern Ukraine, $51.4 \%$ higher than in Central Ukraine, $82.5 \%$ higher than in Southern Ukraine and more than twice as high as in Western Ukraine. Fourthly, in the years 2004-2008, labour productivity grew the fastest in Central Ukraine (6.6\% annually). Fifthly, the recession in 2009-2010 (resulting from the global financial crisis and the gas conflict with Russia) led to an average annual decrease in labour productivity in 2008-2010 of 5.8\% in Eastern Ukraine, $4.7 \%$ in Western Ukraine, 3.0\% in Central Ukraine, 2.8\% in Southern Ukraine and $2.3 \%$ in Northern Ukraine. Sixthly, immediately before Euro-Maidan, the regions of Northern Ukraine (average annual labour productivity growth rates were 5.6\%) developed the fastest, followed by Western Ukraine (4.7\%), Central Ukraine (3.5\%) and Southern Ukraine (1.9\%), while in Eastern Ukraine the value of this macroeconomic variable fell at a rate of $4.8 \%$ at that time. Seventhly, in 2014, mainly as a result of the war in Donbas, labour productivity in

(Northern Ukraine), 23.6\% (Eastern Ukraine), 11.8\% (Southern Ukraine with the autonomous Republic of Crimea and Sevastopol) and $20.1 \%$ (Central Ukraine). 
Eastern Ukraine fell by as much as $17.2 \%^{12}$. In the years $2015-2016$ labour productivity in Eastern Ukraine increased by $28.9 \%$, but it should be stressed that this was due to the fact that in this period the GDP fell more slowly than the number of employees. Real GDP fell by $16.0 \%$ (in Luhansk oblast by $38.4 \%$, Donetsk oblast by $29.4 \%$ ), while the number of workers in eastern Ukraine decreased by $35.0 \%$ (in Luhansk oblast by $66.0 \%$, and Donetsk oblast by $57.3 \%$ ).

Eighthly, in 2015, the GDP of Western Ukraine fell by $8.6 \%$, in the North and Centre by $6.9 \%$, and in the south by $3.0 \%$. Ninthly, the growing Ukrainian GDP in 2016 led to an increase in labour productivity of $4.5 \%$ in Northern Ukraine, $4.1 \%$ in Southern Ukraine, 3.0\% in Central Ukraine and a decrease of $0.4 \%$ in the GDP per worker in Western Ukraine.

As a result of these changes, Northern Ukraine's productivity in 2016 was $54.3 \%$ higher than in the centre of Ukraine, $65.7 \%$ higher than in the east, $110.7 \%$ higher than in the south and $167.0 \%$ higher than in the west. This means that despite the ongoing political and economic cycle, Northern Ukraine's regions (mainly Kyiv and Kyiv oblast) are developing faster than the other groups of regions.

\section{Model parameters calibration of and numerical simulations}

The parameters of the gravitational model of economic growth have been calibrated from historical data on Ukrainian regions (see point 2). The function of labour productivity (described by equation 1) takes into account not only domestic gravitational effects, but also foreign gravitational effects (coming from Poland and Russia). The extended performance function is given by the following equation:

and after logarithmizing:

$$
y_{i t}=a\left(k_{i t}\right)^{\alpha}\left(g_{i t}\right)^{\beta}\left(g_{i t}^{P}\right)^{\gamma}\left(g_{i t}^{R}\right)^{\delta},
$$

where:

$$
\ln y_{i t}=\ln a+\alpha \ln k_{i t}+\beta \ln g_{i t}+\gamma \ln g_{i t}^{P}+\delta \ln g_{i t}^{R}
$$

$a>0$ means total factor productivity, $\mathrm{k}_{\mathrm{it}}$ capital per employee in the $i$-th region in year $t, g_{i t}$ total domestic gravity effects in the $i$-th region in year $t, g_{i t}^{P}$ foreign gravity effects from Poland in the $i$-th region in year $t$, and $g_{i t}^{R}$ foreign gravity effects from Russia in the $i$-th region in year $t$. The parameters of equation (11) were calculated with two methods - the method of least squares and the generalised method of moments. The results of the estimates are summarised in Table 1. In estimates the generalised moment method is using, instrumental variables are dependent variables and independent variables delayed by one year.

Table 1. Estimated parameters of the equation (11)

\begin{tabular}{ccc}
\hline Explanatory variable & LSM & GMM \\
\hline $\ln \boldsymbol{a}$ & $3.1899^{* *}$ & $3.7629^{* *}$ \\
& $(11.0885)$ & $(12.5181)$ \\
\hline $\ln \boldsymbol{k}_{\boldsymbol{i t}}$ & $0.3795^{* *}$ & $0.3024^{* *}$ \\
& $(8.0305)$ & $(6.153873)$ \\
\hline $\ln \boldsymbol{g}_{\boldsymbol{i t}}$ & $0.05050^{*}$ & $0.07939^{* *}$ \\
& $(2.0598)$ & $(3.1533)$ \\
\hline $\ln \boldsymbol{g}_{\boldsymbol{i t}}^{\boldsymbol{P}}$ & $0.04645^{* *}$ & $0.08624^{* *}$ \\
& $(3.2358)$ & $(5.6069)$ \\
\hline $\ln \boldsymbol{g}_{\boldsymbol{i t}}^{\boldsymbol{R}}$ & $0.2109 * *$ & $0.2679 * *$ \\
& $(9.0775)$ & $(10.8321)$ \\
\hline
\end{tabular}

\footnotetext{
12 This was due both to drastic falls in real GDP and the number of employees. In Luhansk oblast in 2014 GDP fell by as much as $45.1 \%$, in Donetsk oblast by $30.7 \%$. The number of employees decreased by $65.1 \%$ in Luhansk oblast and $56.8 \%$ in Donetsk oblast.
} 


\section{Source: own compilation}

The t-Student statistics are given in brackets below the estimates:

** - statistically significant variables at $1 \%$ significance level,

* - statistically significant variables at $5 \%$ significance level.

Source: own calculation based on http://www.ukrstat.gov.ua/ .

From the results summarised in Table 1 it can be concluded that all the parameters of equation (11) were statistically significant to at least the 5\% significance level. In numerical simulations, the following form of labour productivity functions has been assumed:

$$
y_{i t}=32,34\left(k_{i t}\right)^{0,341}\left(g_{i t}\right)^{0,0649}\left(g_{i t}^{P}\right)^{0,0663}\left(g_{i t}^{R}\right)^{0,239} \text {. }
$$

The parameters in equation (12) were determined by averaging the values of parameters obtained by the least squares method and the generalised moments method. Functional parameters (12) can be economically interpreted as follows: labour productivity in a given Ukrainian regions will react most strongly to changes in working capital (i.e. internal potential of the oblast), slightly less to changes in foreign gravitational effects coming from Russia, and much less to changes in foreign gravity effects coming from Poland and domestic influences.

In the numerical simulations, it was assumed that in all Ukrainian oblasts the rate of capital loss per employee is the same and amounts to $14 \%{ }^{13}$. Numerical simulations were performed to make different assumptions concerning the development of the investment rates in the Ukrainian regions, the number of administrative units and interest on Polish and German capital per worker growth.

In the case of investment rates, the following two options were considered:

1. In subsequent years, investment rates will be the same for all oblasts, equal to the average investment rate for the whole Ukraine for the years 2004-2017 (i.e. 19.3\%).

2. The investment rates will vary in oblast, and their structure will be the same as in the years 2004-2017.

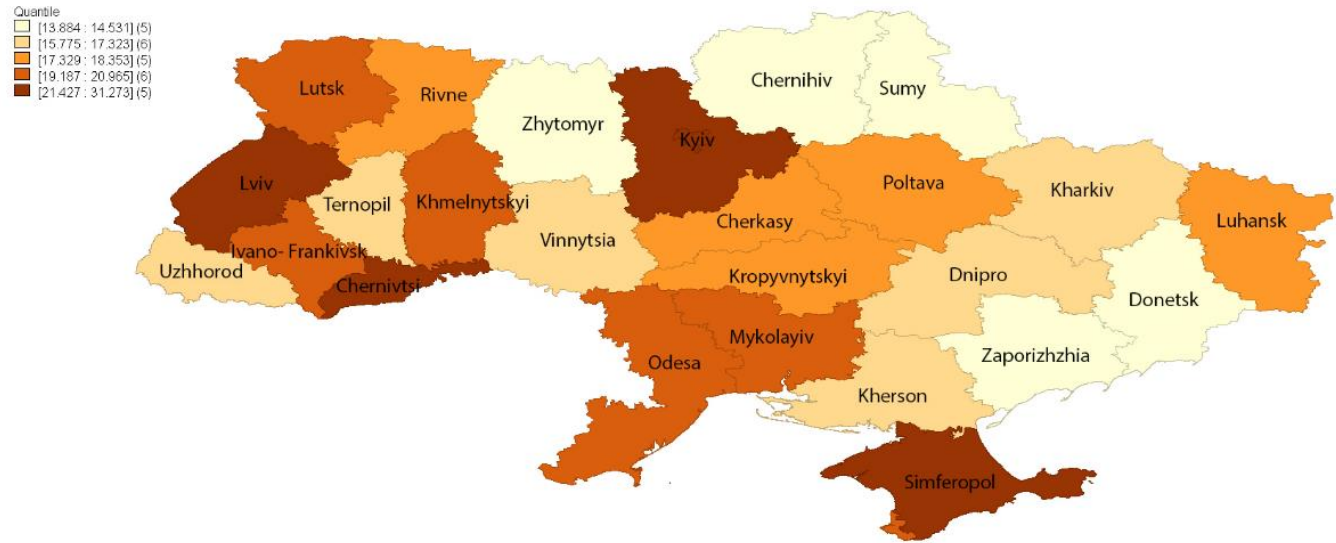

Map 6. Investment rates in Ukrainian oblasts in 2004-2017 (\% of GDP) in the case of Autonomous Republic of Crimea and Sevastopol in 2004-2013

Source: own calculation based on http://www.ukrstat.gov.ua.

\footnotetext{
${ }^{13}$ The rate of loss of capital per employee was estimated on the basis of historical data for the entire Ukrainian economy.
} 


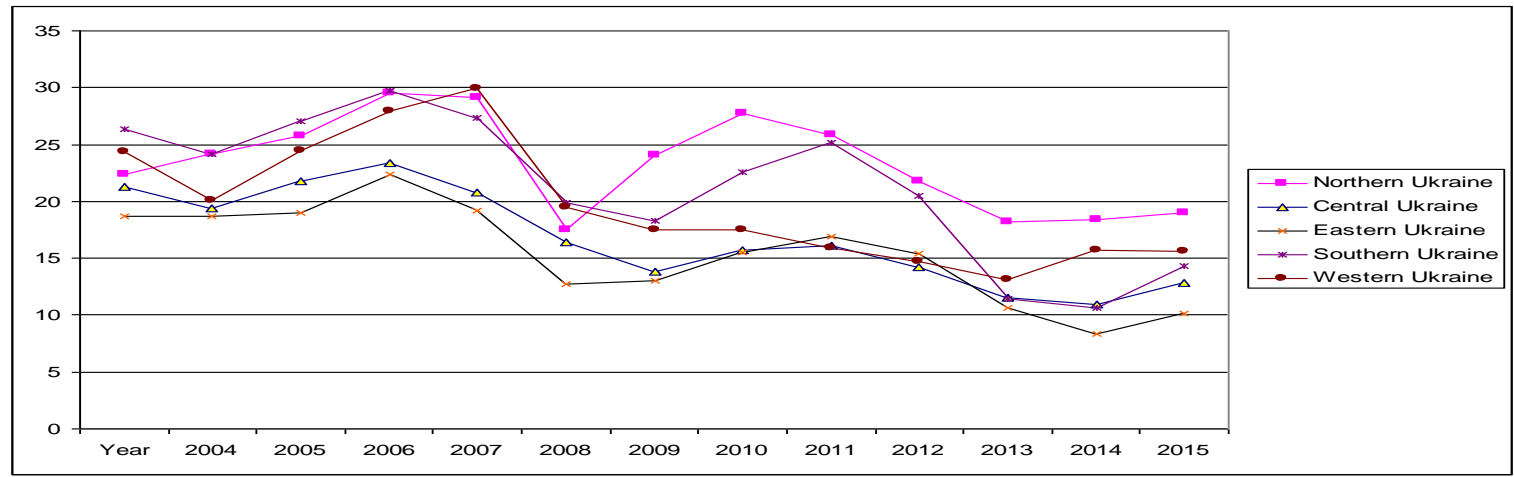

Figure 3. Investments rates in the groups of Ukrainian regions in 2004-2015 (\% of GDP) Source: own calculation based on http://www.ukrstat.gov.ual

In these years, the following regions were characterised by far the highest investment rates: Kyiv oblast (31.3\%), the Autonomous Republic of Crimea (30.9\%) and Kyiv (24.2\%), while the following regions were characterised by the lowest investment rates: Donetsk (14.5\%), Zaporizhzhia (14.4\%), Zhytomyr (14.4\%), Chernihiv (14.0\%) and Sumy (13.9\%, see Map 6 and Figure 3).

In numerical simulations, two options concerning the number of Ukrainian regions were also considered. The first assumed that the Autonomous Republic of Crimea and the city Sevastopol remain outside the Ukrainian administration ( 25 oblasts), in the second these areas are reintegrated into Ukraine ( 27 oblasts). Finally, two variants were also adopted in relation to capital growth rates per worker in Poland and Russia, i.e. the average value for the years 20042017 (Poland 3.53\%, Russia 2.24\%) and for the years 2010-2017 (Poland 2.56\%, Russia $0.84 \%$ ). Different assumptions concerning the formation of exogenous variables in the gravitational growth model allowed eight development scenarios to be built, the list of which is presented in Table 2 .

Table 2. Development scenarios considered in numerical simulations

\begin{tabular}{|c|c|c|c|c|c|c|}
\hline & \multicolumn{2}{|c|}{ Investment rates } & \multicolumn{2}{|c|}{$\begin{array}{l}\text { The growth rate of capital labour } \\
\text { ratio in Poland and Russia }\end{array}$} & \multicolumn{2}{|c|}{ Number of regions } \\
\hline & same & Differing & $2004-2017$ & $2010-2017$ & 27 & 25 \\
\hline Scenario 1 & $\mathrm{X}$ & & $\mathrm{X}$ & & & $X$ \\
\hline Scenario 2 & & $X$ & $\mathrm{X}$ & & & $\mathrm{X}$ \\
\hline Scenario 3 & $X$ & & $\mathrm{X}$ & & $\mathrm{X}$ & \\
\hline Scenario 4 & & $\mathrm{X}$ & $\mathrm{X}$ & & $\mathrm{X}$ & \\
\hline Scenario 5 & $X$ & & & $X$ & & $X$ \\
\hline Scenario 6 & & $\mathrm{X}$ & & $\mathrm{X}$ & & $\mathrm{X}$ \\
\hline Scenario 7 & $\mathrm{X}$ & & & $\mathrm{X}$ & $\mathrm{X}$ & \\
\hline Scenario 8 & & $\mathrm{X}$ & & $\mathrm{X}$ & $\mathrm{X}$ & \\
\hline
\end{tabular}

Source: own elaboration.

Taking into account the adopted assumptions (Table 2), a numerical simulation of labour productivity in Ukrainian administrative oblasts in the years 2018-2050 was conducted. Table 3 summarises the results of these simulations in the above mentioned variants. 
Table 3. Simulations of productivity in the analysed regions in various development scenarios (thou. of hryvnia, prices of 2015)

\begin{tabular}{|c|c|c|c|c|c|c|c|c|c|}
\hline \multirow[t]{2}{*}{ Region } & \multirow{2}{*}{$\begin{array}{l}\text { Produc- } \\
\text { tivity in } \\
2017\end{array}$} & \multicolumn{8}{|c|}{ Productivity in 2050 in variant } \\
\hline & & 1 & 2 & 3 & 4 & 5 & 6 & 7 & 8 \\
\hline $\begin{array}{l}\text { Northern } \\
\text { Ukraine }\end{array}$ & 235.0 & 335.4 & 431.7 & 328.8 & 422.8 & 244.5 & 313.7 & 239.8 & 307.3 \\
\hline $\begin{array}{l}\text { Central } \\
\text { Ukraine }\end{array}$ & 152.4 & 283.7 & 215.6 & 282.2 & 217.5 & 205.8 & 157.1 & 204.7 & 158.5 \\
\hline $\begin{array}{l}\text { Eastern } \\
\text { Ukraine }\end{array}$ & 141.8 & 301.8 & 203.8 & 285.0 & 193.0 & 219.1 & 149.0 & 207.6 & 141.7 \\
\hline $\begin{array}{l}\text { Southern } \\
\text { Ukraine }\end{array}$ & 111.5 & 185.2 & 180.5 & 174.8 & 237.3 & 134.6 & 131.4 & 127.3 & 171.9 \\
\hline $\begin{array}{l}\text { Western } \\
\text { Ukraine } \\
\end{array}$ & 88.0 & 173.9 & 174.2 & 169.9 & 172.0 & 126.3 & 126.6 & 123.4 & 125.0 \\
\hline $\begin{array}{l}\text { Coefficient of } \\
\text { variation in } \\
\text { productivity }\end{array}$ & 0.527 & 0.306 & 0.606 & 0.321 & 0.586 & 0.305 & 0.601 & 0.319 & 0.581 \\
\hline
\end{tabular}

Source: own elaboration.

The results of the numerical simulations for the 8 scenarios allow the following general conclusions to be drawn:

- In the case of Northern Ukraine, regardless of the scenario under consideration, it is always expected to have the largest labour productivity compared to the other groups of oblasts by 2050. Similarly, in each analysed variant, the group of administrative regions included in Western Ukraine is characterised by the lowest expected value of labour productivity by 2050 .

- At the level of individual administrative regions, the Zakarpattia oblast is the last in each scenario in terms of estimated future labour productivity in 2050. The first places in each scenario are taken alternately by: Kyiv City, Kyiv oblast, Sumy (Northern Ukraine), Kharkiv (Eastern Ukraine) and Poltava (Central Ukraine).

- In the scenario of different investment rates for individual oblasts while maintaining their structure from 2004-2017 in the composition of 25 districts (scenario 2), the largest difference in labour productivity in 2050 between the Ukrainian oblasts is expected.

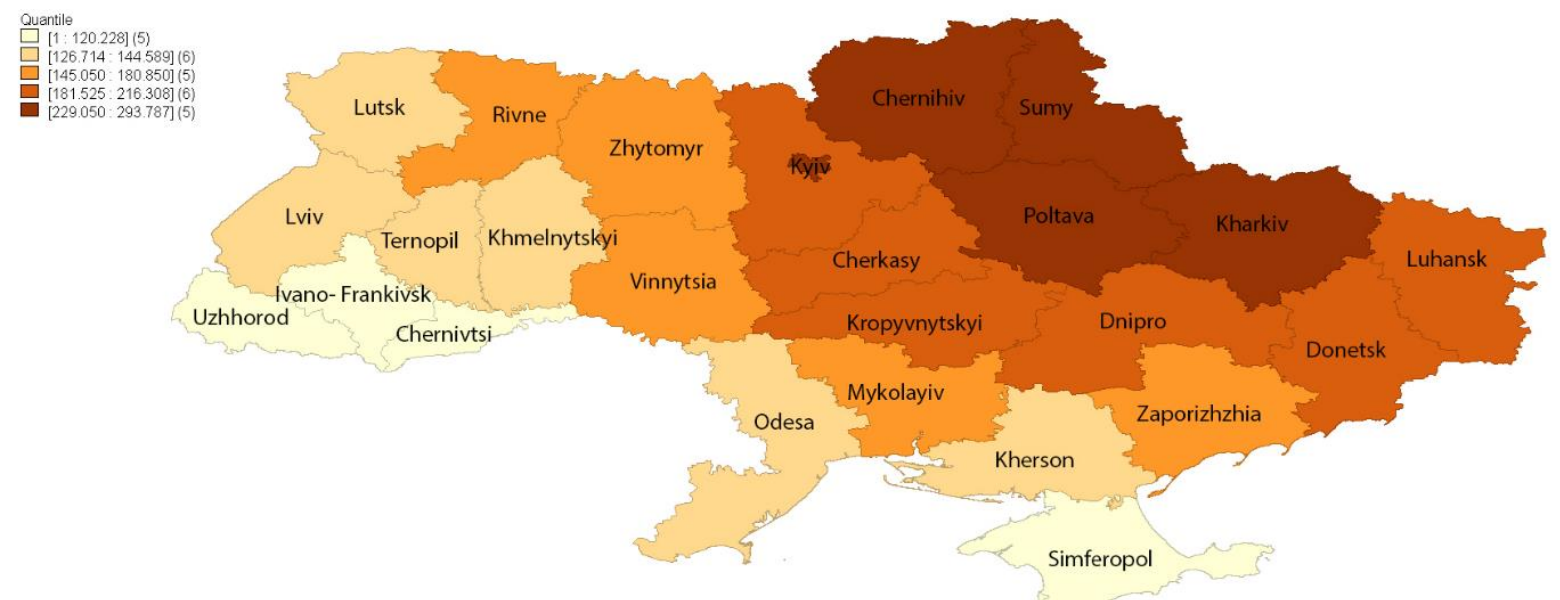

Map 7. Labour productivity in Ukrainian oblasts in 2050 in scenario 5 (thou. UAH)

Source: own calculation based on http://www.ukrstat.gov.ua. 
- The results of the range analysis confirm the sigma-type convergence analysis. The strongest expected convergence in labour productivity is expected under the scenarios: 5, 7 and 3, which is characterised by maintaining the same investment rate for all regions from 20142017 in the period 2018-2050.

- The biggest inequalities between Ukrainian oblasts in terms of labour productivity (technical progress in general) can be expected in the scenarios: 2, 4 and 8, which are characterised by the assumption of maintaining a diversified structure of regional investment rates until 2050.

From the perspective of Kyiv the most favourable scenarios seem to be 2 and 4 -i.e. maintaining the current (2004-2017) investment rate in the next 3 decades. From the perspective of the poorest regions (Zakarpattia, Kherson) the implementation of scenario 3 (investment rate equal to the average investment rate for the whole of Ukraine in the period 2004-2017) suggests the greatest potential for labour productivity growth in 2050 and, consequently, economic growth.

\section{Conclusion}

The years 2001-2008 were the most favourable period for the development of the Ukrainian economy since Ukraine regained independence in 1991. At that time, production volume increased, employment grew, unemployment fell and good conditions for the development of entrepreneurship were created. In 2009, the Ukrainian economy was affected by the recession resulting from the global financial crisis and the gas conflict with Russia. After Euro-Maidan (as a result of the seizure of the Autonomous Republic of Crimea by Russia and the war with pro-Russian separatists in Donbas), the economy was once again in recession.

The conflict in the Donetsk and Luhansk regions combined with hyperinflation led to destabilisation of Ukraine's financial and banking system. The worsening economic situation in Ukraine has led to a reduction in the standard of living, a decrease in employment and an increase in labour migration of Ukrainians.

In each analysed scenario of changes in labour productivity in 2050, Northern Ukraine is always in first place. Similarly, in each analysed variant, the group of administrative regions included in Western Ukraine is characterised by the lowest expected value of labour productivity in 2050 .

Maintaining the existing differentiated regional investment rates for the period 20042017 increases the probability of deepening regional differences in labour productivity over time. Implementation of solutions for equalisation of regional investment rates in regional development policy gives a chance to achieve the lowest economic polarisation till 2050. 


\section{References}

Acemoglu, D. (2009), Introduction to Modern Economic Growth, Princeton University Press, Princeton and Oxford.

Aghion, P., \& Howitt, P. (2009),. The economics of growth. The MIT Press, Cambridge, Massachusetts, London, England.

Barro R.J., \& Sala-i-Martin X. (2004). Economic Growth. MIT Press, Cambridge, MA.

Chugaievska, N., \& Tokarski, T. (2018) Wpływ zmian PKB na przestrzenne zróżnicowanie bezrobocia na Ukrainie [Impact of GDP changes on the spatial diversity of unemployment in Ukraine]. Wiadomości Statystyczne, 3, 50-68.

Chugaievska, S., Chugaievska, N., \& Tokarski, T. (2017). Analyse statistique de l'impact de l'effet gravitationnel sur la diversification du développement économique de l'Ukraine [Statistical analysis of the impact of the gravitational effect on the diversification of the economic development of Ukraine]. Revue Internationale Des Economistes De Langue Française, 2(2), 72-95.

Emsina, A. A. (2014) Labour productivity, economic growth and global competitiveness in post-crisis period. Procedia-Social and Behavioral Sciences, 156(2014), 317-321.

Gricenko, A. A. (red.) (2015). Інституційні трансформації соціально-економічної системи Украӥни [Institutional transformations of the socio-economic system of Ukraine], Інститут економіки та прогнозування НАН України, Київ.

Hrycak, J. (2000). Historia Ukrainy 1772-1999. Narodziny współczesnego narodu [History of Ukraine 1772-1999. The birth of a modern nation], Instytut Europy SrodkowoWschodniej, Lublin.

Hud, B. (2018). Ukraińcy i Polacy na Naddnieprzu, Wolyniu $i$ w Galicji Wschodniej w XIX $i$ pierwszej połowie XX wieku [Ukrainians and Poles in Transnistria, Volhynia and Eastern Galicia in the nineteenth and first half of the twentieth century]. Pracownia, Warszawa.

Kozhemiakina, S. M. (2014). Продуктивність праці: вектор макроекономічних показників [Labour productivity: the vector of macroeconomic indicators]. Ринок праці та зайнятість населення, $\mathrm{nr}$ 4, 49-53.

Mroczek, K., Tokarski, T., Trojak, M. (2014). Grawitacyjny model zróżnicowania rozwoju ekonomicznego województw [Gravitational model of diversification of economic development of voivodships]. Gospodarka Narodowa, 3.

Pastuszka, S., \& Tokarski, T. (2017). Analiza porównawcza przestrzennego zróżnicowania PKB i bezrobocia w Polsce i we Włoszech [A comparative analysis of the spatial diversity of GDP and unemployment in Poland and Italy], Wiadomości Statystyczne nr 3, 49-70.

Pustovoit, O.W. (2016). Українська економіка: хаотичні та циклічні коливання навколо довгострокового тренду зростання [The Ukrainian economy: chaotic and cyclical fluctuations around the long-term growth trend]. Економіка і прогнозування, 2, 86-109.

Romer, D. (2000). Makroekonomia dla zaawansowanych. Wydawnictwo Naukowe PWN, Warszawa.

Serczyk, W.A. (2001). Historia Ukrainy [Ukrainian history]. Zakład Narodowy im. Ossolińskich, Wrocław, Warszawa, Kraków.

Semykina, M. (2010). Продуктивність праці: методологія вимірювання, передумови зростання [Labour productivity: methodology of measuring, pre-conditions of growth]. Наукові праці КНТУ. Економічні http://www.kntu.kr.ua/doc/zb_17_ekon/stat_17/70.pdf.

Solow, R. M. (1956) A Contribution to the Theory of Economic Growth. The Quarterly Journal of Economics, 70(1), 65-94.

Solow, R. M. (1979). Another possible source of wage stickiness. Journal of Macroeconomics, No. $1,79-82$. 
Tokarski, T. (2009). Matematyczne modele wzrostu gospodarczego. Ujęcie neoklasyczne, Wydawnictwo Uniwersytetu Jagiellońskiego, Kraków.

Tokarski, T. (2011). Ekonomia matematyczna. Modele makroekonomiczne. Polskie Wydawnictwo Ekonomiczne, Warszawa.

Zhurska, O. (2018). Диверсифікація як метод підвищення економічної ефективності підприємства [Diversification as a method of improvement of economic efficiency of an enterprise], Інвестиції: практика та досвід, 13, 16-21.

Żółtowska, E. (1997). Funkcja produkcji. Teoria, estymacja, zastosowania. Wydawnictwo Uniwersytetu Łódzkiego, Łódź. 